\title{
Gully Erosion Problems in Selected Areas of Edo State: Factors and Control
}

\author{
Kayode-Ojo N. ${ }^{1, *}$, Ikhide A. O. ${ }^{2}$ and Ehiorobo J. O. ${ }^{3}$ \\ ${ }^{1,2,3}$ Department of Civil Engineering, University of Benin, Benin City, Edo State, Nigeria \\ Corresponding Author: *engrngozi@yahoo.com
}

\begin{abstract}
Gully erosion is a serious ecological problem in Edo State and has negative impact on agricultural productivity, lives and properties in both urban and rural environments. This paper therefore aims at identifying factors contributing to the formation of gullies and methods of controlling them so that further environmental degradation would be averted. Three gully sites were selected from the three geo-political zones of the State. Data were collected through remote sensing, field topographical survey and soil sampling on gully walls and gully beds. Meteorological and hydrological data were also collected. Slope stability analysis was also carried out. The KerbyKirpich equation was applied to estimate the overall time of concentration and Rational formula used to determine the peak discharge. The study revealed that the selected study areas possess all the characteristics of an erosion prone area which are: rainfall of very high intensity, steep slopes resulting in large runoff and soil with low organic content and relatively low shear strength obtained from the geotechnical investigations. Results from the studies revealed that the gully width and depth varied considerably from top to bottom. The cross section shows that the gully is $U$ shaped for Ekehuan gully and V-shaped for Auchi and Ewu gullies, indicating a large catchment area and a large volume of discharge passing through the gully.
\end{abstract}

Keywords: Gully erosion, Topographical survey, Meteorological survey, Hydrological survey, Slope stability

\subsection{Introduction}

Gully erosion is caused when runoff concentrates and flows at a velocity sufficient to detach and transport soil particles. A waterfall may form, with runoff picking up energy as it plunges over the gully head. Splash back at the base of the gully head erodes the subsoil and the gully eats its way up the slope (Bruce, 2006).

Urban degradation is drawing concern in Edo state, it has been estimated that land loss due to gully erosion, sheet - rill erosions constitute about $5 \%$ of degraded land. High land use pressure as a result of increasing migration of population to urban areas renders the landscape more vulnerable to gully erosion. Many of the gullies within urban landscape in Edo State were formed mainly as a result of improper termination of drains and water courses. A major cause of gully erosion in the study area is roads constructed with inappropriately terminated drainage network. While damages by surface runoff to the roads may be limited, offsite effects can be severe (Ehiorobo and Izinyon, 2011).

The road is said to induce a concentration of surface runoff with a concentrated diversion of concentrated runoff to other catchment and an increase in catchment size enhances gully development after road construction (Nyssen et al., 2002). Changes in drainage pattern associated with urbanization result in gullying particularly where illegal settlement without urban infrastructure exist (Ehiorobo and Izinyon, 2012). One of the most basic but non-renewable resource is soil and once lost, is difficult and costly to replace within near future. Gully processes are usually the main sources of sedimentation (Hum et al., 2005). Research carried out by various researchers have shown that gully erosion represents one of the most soil degradation process in Nigeria as it causes considerable soil 
loss, and produces large volume of sediment. Gullies are also catalyst for transferring surface runoff and sediment from upland to valley floors and creating up channels that aggravate the problem of flooding and water pollution. Many cases of damages to water courses and properties by runoff from agricultural land relate to the occurrence of gully erosion (Verstraeten and Poesen, 1999; Boardman, 2001; Poesen et al., 2003).

By the day, gully erosion has attained a larger and devastating dimension in Edo state that has attracted international interventions. All the senatorial districts in the state have their fair share of the problem. In Edo south, the main gully erosion sites are; Queen Ede, West moat Ekehuan Road, University of Benin (Ugbowo campus) and Costain. In Edo North, the main gully sites are; Auchi gully complex and Ikabigbo gully while the main gully sites in Edo Central are; Ewu gully and Ibore gully. The aim of this research work is to identify factors contributing to the formation of gullies and methods of controlling them so that further environmental degradation would be averted.

\subsection{Materials and Methods}

\subsection{Description of study area}

Edo State is located in the south-south zone of Nigeria between Latitude $5^{\circ} 44^{\prime} 60^{\prime \prime} \mathrm{N}$ to $7^{\circ} 33^{\prime} 45^{\prime \prime} \mathrm{N}$ and Longitude $5^{\circ} 05^{\prime} 45^{\prime \prime} \mathrm{E}$ to $6^{\circ} 38^{\prime} 18^{\prime \prime} \mathrm{E}$ (see Figure 1). It covers an area of about $19,853 \mathrm{~km}^{2}$. The State is made up of 18 local government areas (LGAs) and a total population of 3,233,366 (based on the 2006 National Population census).

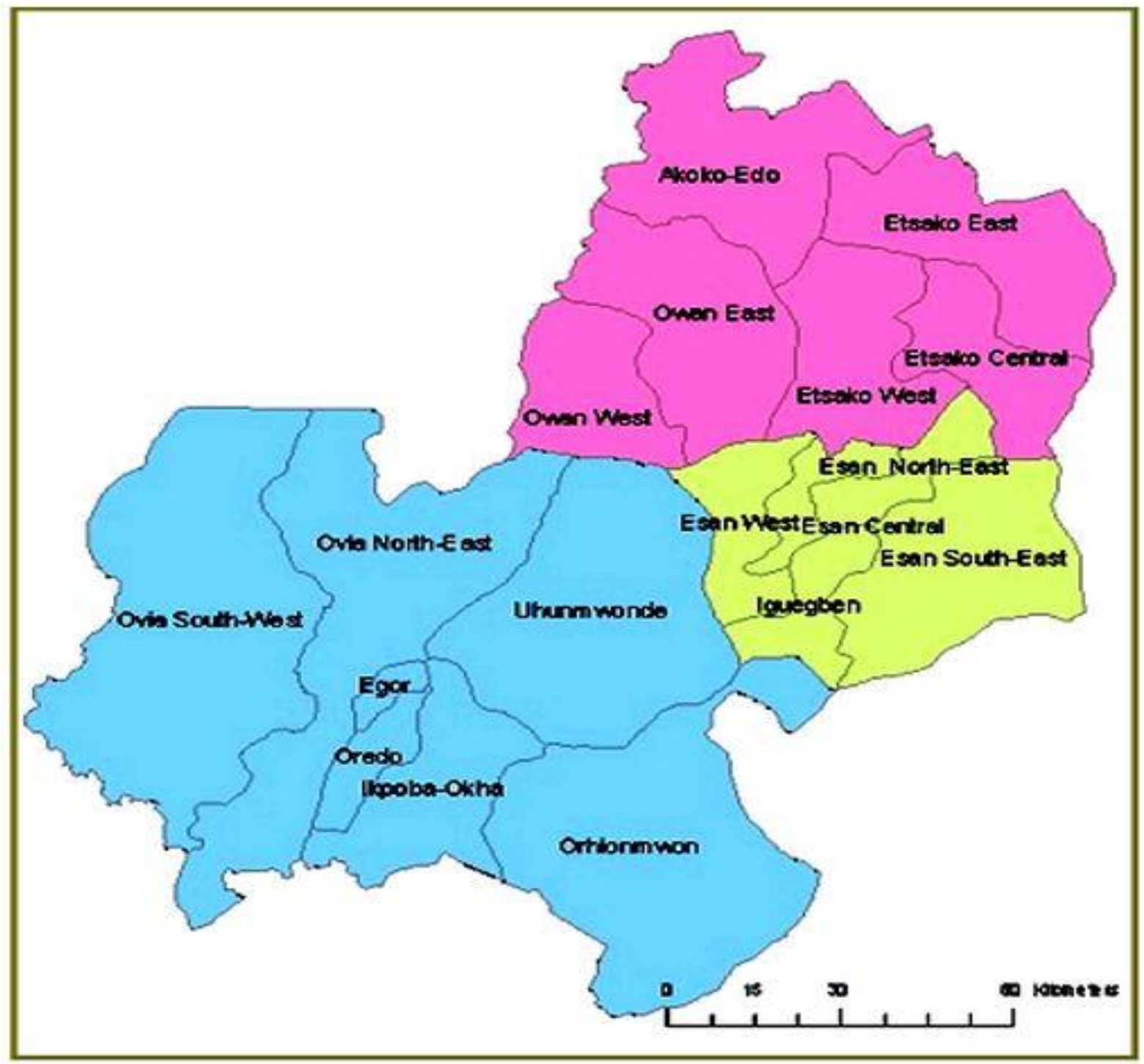

Figure 1: Map of Edo State showing the 18 Local Government Areas (www.nigerianmuse.com) 
The region has a low land of roughly $16,992 \mathrm{~km}^{2}$ and high land of approximately $1,586 \mathrm{~km}^{2}$ (Fabiyi et al., 2012). Basically, the topography of the State consists of a rugged high land in the north which extended down to the central part of the region. The high land is dissected by a wide valley which stretches from the Niger River floodplain in the east to the western margin of the State. In the south, the topography is a gentle sloping plane that extends into Delta State (Asikhia and Nkeki, 2014).

\subsection{Data collection}

Edo state is divided into three senatorial zones; Edo South, Edo Central and Edo North. For the purpose of this study, one gully site was selected from each of the three senatorial zones. In the south; West Moat Ekehuan Road gully erosion site, Benin City, Egor Local Government Area was selected. In the central; Ewu gully erosion site in Esan Central Local Government Area was selected. In the north; Auchi gully complex in Etsako West Local Government Area was selected. For the collection of data for the above selected gully sites, the following methods were adopted.

\subsubsection{Reconnaissance survey}

Desk studies for the evaluation of topographical maps, satellite images and other data collected from Edo State Ministry of Environment and Sustainability to determine the erosion devastated area along the flood routes, erosion gullies, direction of storm runoff, etc. as well as field reconnaissance and indepth site appraisal.

\subsubsection{Topographical survey}

Here, ground survey is carried out and this involves the determination of the gully elevation, profile, longitudinal and transverse sections at a regular interval not more than $25 \mathrm{~m}$, catchment area, and the gully dimensions using Total Station.

\subsubsection{Collection and analysis of meteorological data}

Rainfall data as provided by the Nigerian Meteorological Agency was analyzed to determine the Rainfall Intensity (mm/hr), Rainfall Duration (how many hours it rained at that intensity) and Rainfall Frequency (how often that rain storm repeats itself).

\subsubsection{Geotechnical investigations}

Here the geotechnical condition of the gully sites was studied, sampling (disturbed and undisturbed) was carried out to determine soil properties and assess foundation condition. The soil investigations that were conducted are Particle Size Analysis, Specific Gravity Test, Natural Moisture Content, Atterberg Limit Test, Compaction Test, Undrained Triaxial Test, and Shear Box Test and California Bearing Ratio (CBR) test. All the laboratory tests were conducted in accordance with the general specification given in the British Standard Specifications B.S 1377: 1975; - "Method of Testing Soils for Civil Engineering Purposes" and American Standard Testing Method (ASTM) and also Unified Soil Classification System (USCS).

\subsubsection{Hydrological studies}

This involves the generation of a safe design runoff rate. The factors involved in this are mainly rainfall and watershed characteristics. The rainfall characteristics are the rainfall amount, intensity and its distribution pattern. Similarly, the watershed characteristics such as shape, size and land use pattern affects the runoff rate. The hydrological data obtained from Nigerian Meteorological Agency was used for this analysis. To account for the extreme climatic variability in the future due to climate change (analyzing the worst case scenario), a $20 \%$ increase in rainfall was assumed to occur using the historical data set (FEWS NET, Nigeria Special Report, June 1, 2016).

\subsection{Results and Discussion}

\subsection{West Moat Ekehuan Road Gully}

This study was conducted at West Moat Ekehuan road gully, Egor Local Government Area of Benin city, Edo State. The gully is located at geographical co-ordinates N06¹9'43.07” and E05'35'24.24" as shown in Figure 2. 

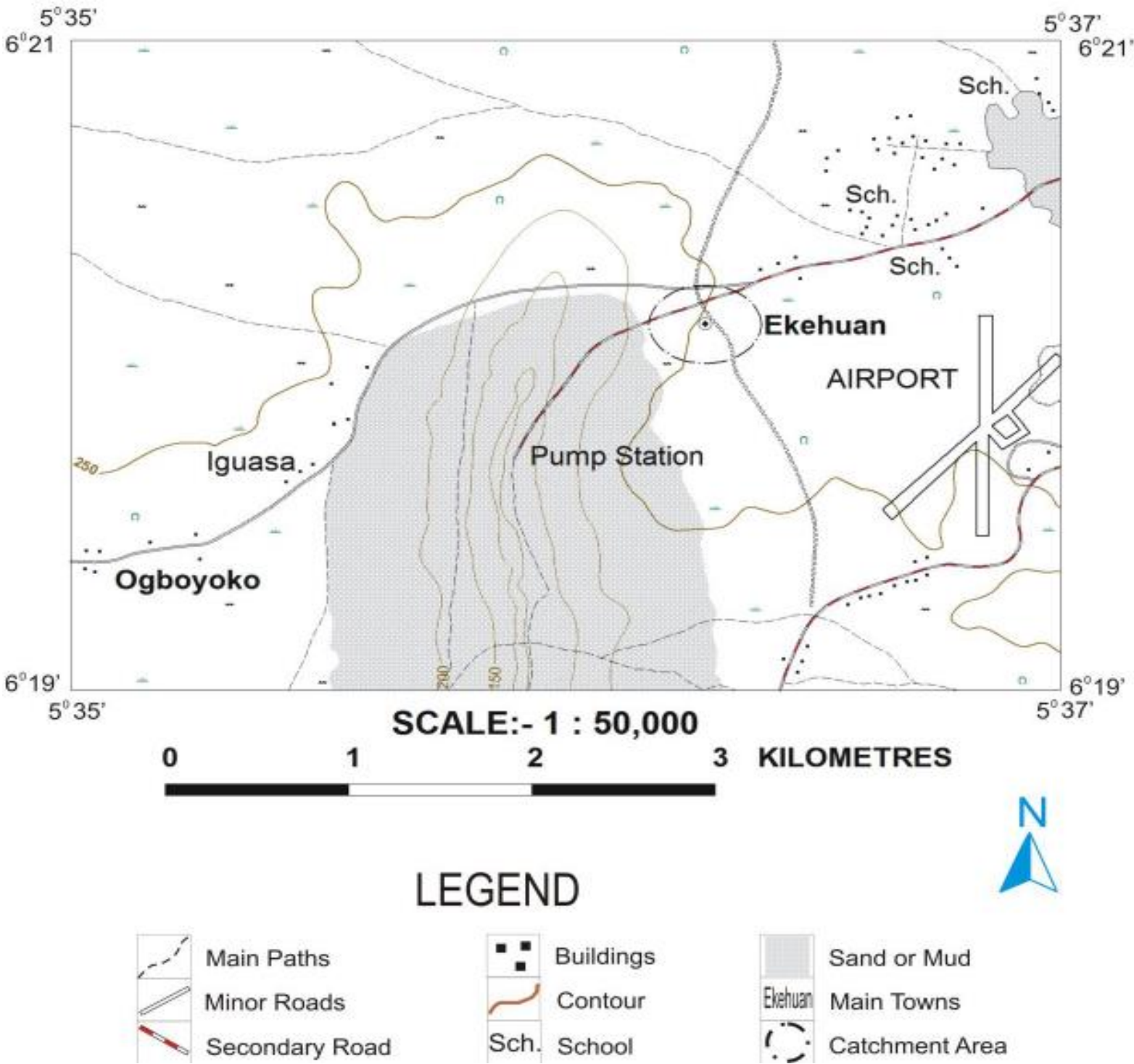

Figure 2: Location Map of Ekehuan Delineated from the Federal Ministry of Lands and Housing (1989)

The gully problem in this area started as a result of the inadequacy of the side drains along Ekehuan road and the diversion of all runoff from the slope running right through Ekehuan road from Agbomwonba through the University of Benin and end down to the culvert crossing the road into the current gully location. Originally, the current gully was a moat but as a result of excessive runoff into the moat channel, it started cutting both headways at the banks and floor. Recent efforts made by the State Government to control the gully by filling the head with boulders has not been successful as the storm runoff undermined the boulders cutting new gullies along the banks and eventual bank slumping and collapse of the walls occurred, particularly at the area around the wood factory (EDO NEWMAP, 2014).

\subsubsection{Findings of the hydrological study (West Moat, Ekehuan Road Gully)}

Table 1 shows the values derived from ArcView GIS for West Moat Ekehuan Road Gully Station for a 24-hour duration while the Rainfall Intensity-Duration-Frequency (IDF) curve is shown in Figure 3.

Table 1: West Moat Ekehuan Road Gully Station's value for 24-hour duration as derived from ArcView GIS

\begin{tabular}{|l|l|l|l|l|l|l|}
\hline Return Period & $100-$ Year & 50 -Year & 25-Year & $10-$ Year & 5-Year & 2-Year \\
\hline $\begin{array}{l}\text { Rainfall } \\
\text { Intensity } \\
(\mathrm{mm} / \text { hour })\end{array}$ & 8.21 & 7.81 & 7.41 & 6.71 & 6.20 & 5.30 \\
\hline
\end{tabular}




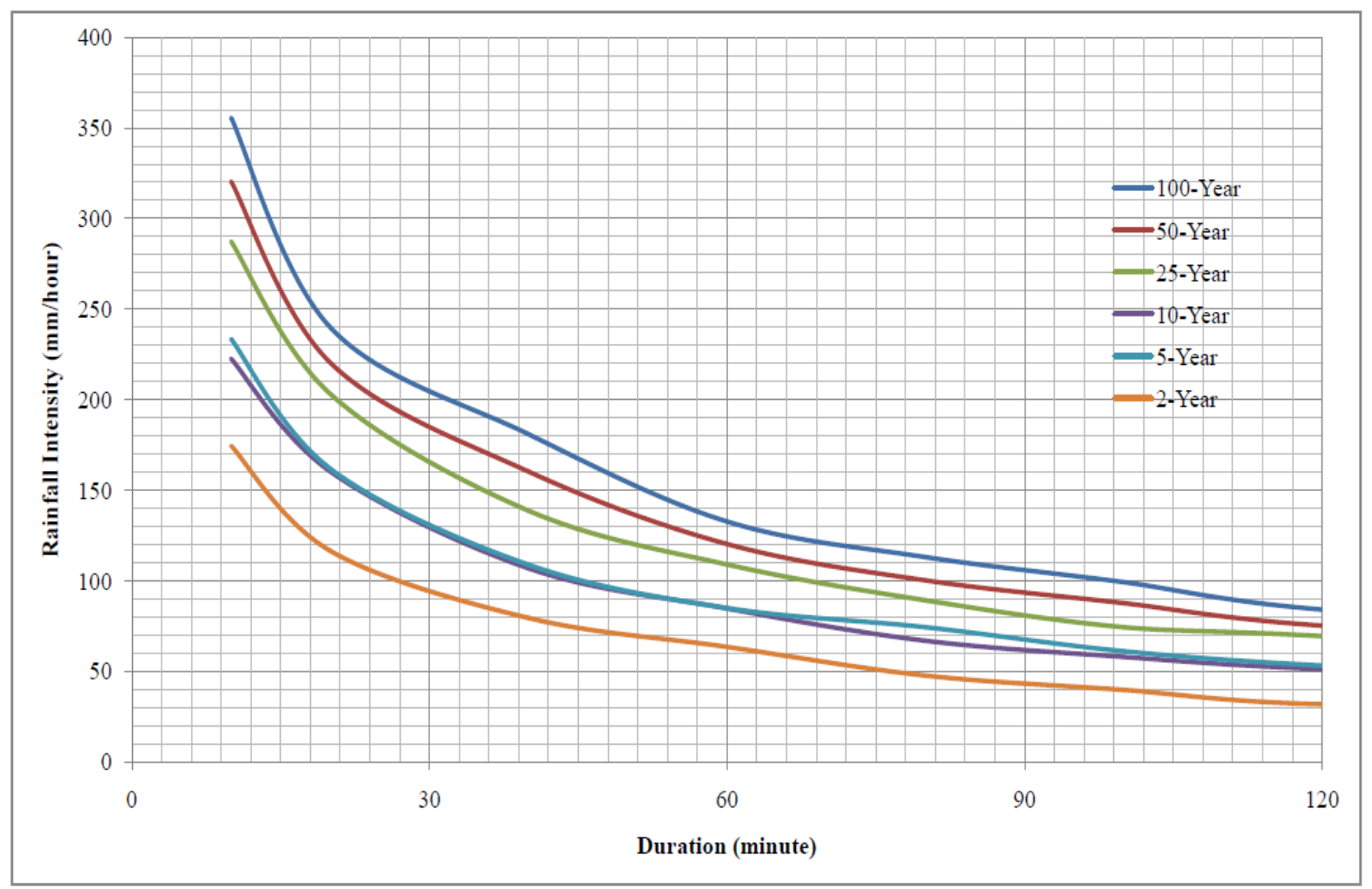

Figure 3: Developed rainfall intensity-duration-frequency curve for Ekehuan Road gully

According to the IDF curve, rainfall estimates are increasing with increase in the return period and the rainfall intensities decrease with rainfall duration in all return periods. The model (curve) predicted higher intensities within durations less than 30 minutes across the different return periods, which indicate a higher erosive power of the surface runoff during this period (duration) when compared to durations of 60 minutes, 90 minutes and 120 minutes. Rainfall intensities rise in parallel with the rainfall return periods.

The watershed/catchment area for Ekehuan road gully erosion site is about 176.19 ha at the gully head, about 201.60 ha at the middle of the gully, and about 439.10 ha at the outlet of the gully as shown in Figure 4.

Based on the findings of the hydrological studies, the cross section shows that the gully is U-shaped, indicating a large catchment area and a large volume of discharge passing through the gully. Also taking into consideration the size of the gully (length and depth), the continuation of the gully, the discharge of runoff and the size of the watershed/catchment area, it is described as a large discontinuous gully. The study also revealed that the study area possesses all the characteristics of an erosion prone area because of the high intensity of rainfall over the area.

3.1.2. Findings of the Geotechnical study (West Moat, Ekehuan Road Gully)

The results of the laboratory tests are shown in Table 2. 


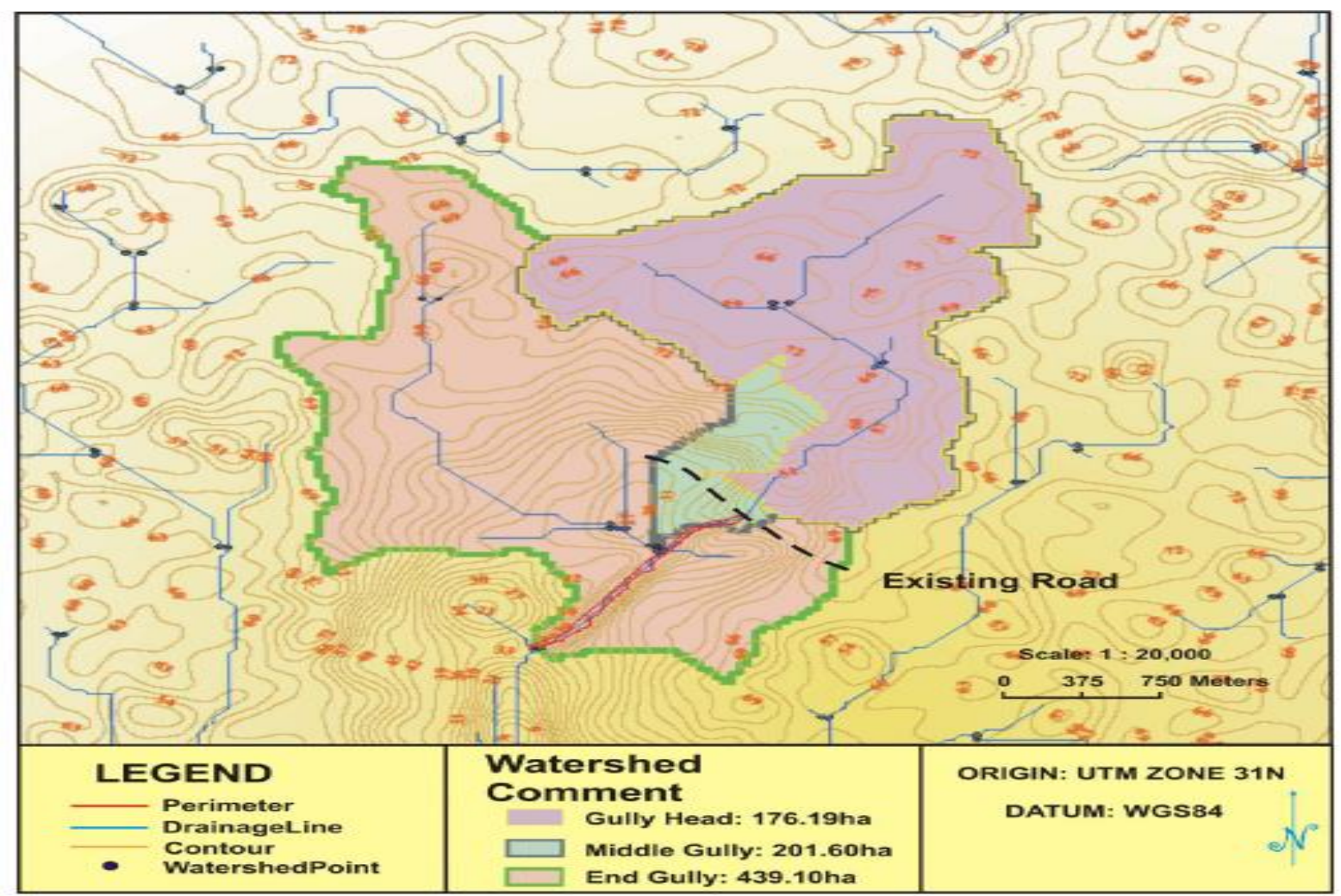

Figure 4: Catchment area delineation for Ekehuan (EDO NEWMAP, 2014)

Table 2: Soil test summary sheet

\begin{tabular}{|c|c|c|c|c|c|c|c|c|c|c|c|c|c|c|}
\hline \multirow[t]{2}{*}{$\mathrm{S} / \mathrm{N}$} & \multirow[t]{2}{*}{ BH No } & \multirow[t]{2}{*}{$\begin{array}{l}\text { Specific } \\
\text { Gravity }\end{array}$} & \multicolumn{3}{|c|}{ Percentage passing sieve } & \multicolumn{3}{|c|}{ Atterberg limit test } & \multirow[t]{2}{*}{$\begin{array}{l}\mathrm{MDD} \\
\left(\mathrm{g} / \mathrm{cm}^{3}\right)\end{array}$} & \multirow[t]{2}{*}{$\begin{array}{l}\text { OMC } \\
(\%)\end{array}$} & \multicolumn{2}{|c|}{ Compression } & \multicolumn{2}{|c|}{$\begin{array}{l}\text { Shear } \\
\text { strength }\end{array}$} \\
\hline & & & $\begin{array}{l}1.18 \\
\mathrm{~mm}\end{array}$ & $\begin{array}{l}0.425 \\
\mathrm{~mm}\end{array}$ & $\begin{array}{l}0.075 \\
\mathrm{~mm}\end{array}$ & $\begin{array}{l}\mathrm{LL} \\
(\%)\end{array}$ & $\begin{array}{l}\text { PL } \\
(\%)\end{array}$ & $\begin{array}{l}\text { PI } \\
(\%)\end{array}$ & & & $\begin{array}{l}\mathrm{C} \\
\left(\mathrm{kN} / \mathrm{m}^{2}\right)\end{array}$ & $\begin{array}{l}\Phi \\
\left({ }^{\circ}\right)\end{array}$ & $\begin{array}{l}\mathrm{C} \\
(\mathrm{kPa})\end{array}$ & \begin{tabular}{|l|}
$\Phi$ \\
$\left({ }^{\circ}\right)$ \\
\end{tabular} \\
\hline 1 & PT1 & 2.51 & 98 & 70 & 31 & 39 & 17 & 22 & 1.76 & 15 & 42 & 17.5 & 58 & 24 \\
\hline 2 & PT2 & 2.60 & 97 & 68 & 32 & 42 & 17 & 25 & 1.80 & 13 & 38 & 13 & 50 & 20 \\
\hline 3 & PT3 & 2.55 & 98 & 67 & 36 & 52 & 16 & 36 & 1.77 & 15 & 57 & 21 & 45 & 22 \\
\hline 4 & PT4 & 2.58 & 98 & 69 & 39 & 51 & 19 & 32 & 1.79 & 15 & 37 & 24.5 & & \\
\hline Ave. & & 2.56 & 98 & 68 & 34 & 46 & 17 & 29 & 1.78 & 14 & 43.5 & 19 & 51 & 22 \\
\hline
\end{tabular}

From the soil summary sheet, specific gravity of the soil samples ranged from 2.51 to 2.60 with an average of 2.56, indicating that the soil is sandy with a higher presence of porous particles. The liquid limit ranged from $39 \%$ to $52 \%$ with an average of $46 \%$. The plastic limit ranged from $16 \%$ to $19 \%$ with an average of $17 \%$, indicating that the soil is non-plastic. From the compaction properties of the soil conducted, it showed that the optimum moisture content ranged from $13 \%$ to $15 \%$ with an average of $14 \%$, indicating the presence of clayey soil. The minimum plasticity showed that the soil has a tendency to be eroded by water. Therefore, in the period of the rainy season, the soil in the area is likely to be eroded; and this is usually the period of gully recession and bank slumping.

The maximum dry density ranged from $1.76 \mathrm{~g} / \mathrm{cm}^{3}$ to $1.80 \mathrm{~g} / \mathrm{cm}^{3}$ with an average of $1.78 \mathrm{~g} / \mathrm{cm}^{3}$. The soil sample showed cohesion that ranged from $38 \mathrm{kN} / \mathrm{m}^{2}$ to $57 \mathrm{kN} / \mathrm{m}^{2}$ with an average of $43.5 \mathrm{kN} / \mathrm{m}^{3}$. The angle of internal friction ranged from $13^{\circ}$ to $25^{\circ}$ with an average of $19^{\circ}$, indicating that the soil is very loose. From the shear strength, the cohesion of the soil ranged from $45 \mathrm{kPa}$ to $58 \mathrm{kPa}$ with an average of $51 \mathrm{kPa}$ and the angle of internal friction $(\varphi)$ value ranged from $20^{\circ}$ to $24^{\circ}$ with an average of $22^{\circ}$, indicating that the soil is soft-firm silty clay/clayey silt.

From the sieve analysis test conducted, see Figure 4.4, the percentage passing sieve No $1.18 \mathrm{~mm}$ ranged from $97.24 \%$ to $98.07 \%$ with an average of $97.83 \%$. The percentage passing sieve No $0.425 \mathrm{~mm}$ ranged from $69.67 \%$ to $66.90 \%$ with an average of $68.30 \%$ while the percentage passing sieve $0.075 \mathrm{~mm}$ ranged from $31.19 \%$ to $38.67 \%$ with an average of $34.46 \%$. This indicates that the soil is silty or clayey sand. It is deduced that the soil(s) is fine grained with its drainage characteristics rated as fair to poor and also practically impervious. Based on the above results, using the unified soil 
classification system, the soil lies above the "A line" in the plasticity index chart. Therefore, the soil sample can be classified as under Soil Group SM with the name, silty sands poorly graded and nonplastic. The result of the above assertions is that the soil has a tendency to be eroded by weathering agent mostly by water. Therefore, adequate control measures should be put in place to prevent further expansion of the gully.

\subsection{Auchi gully complex}

\subsubsection{Findings of the hydrological study}

Table 3 shows the values derived from ArcView GIS for Auchi gully site station for a 24-hour duration and the Rainfall Intensity-Duration-Frequency (IDF) curve is shown in Figure 5.

Table 3: Auchi gully site station's value for a 24-hour duration as derived from Arcview GIS

\begin{tabular}{|l|l|l|l|l|l|l|}
\hline Return Period & $100-$ Year & $50-$ Year & 25-Year & $10-$ Year & 5-Year & 2-Year \\
\hline $\begin{array}{l}\text { Rainfall } \\
\text { Intensity } \\
\text { (mm/hour) }\end{array}$ & 8.64 & 8.05 & 7.45 & 6.59 & 5.91 & 4.75 \\
\hline
\end{tabular}

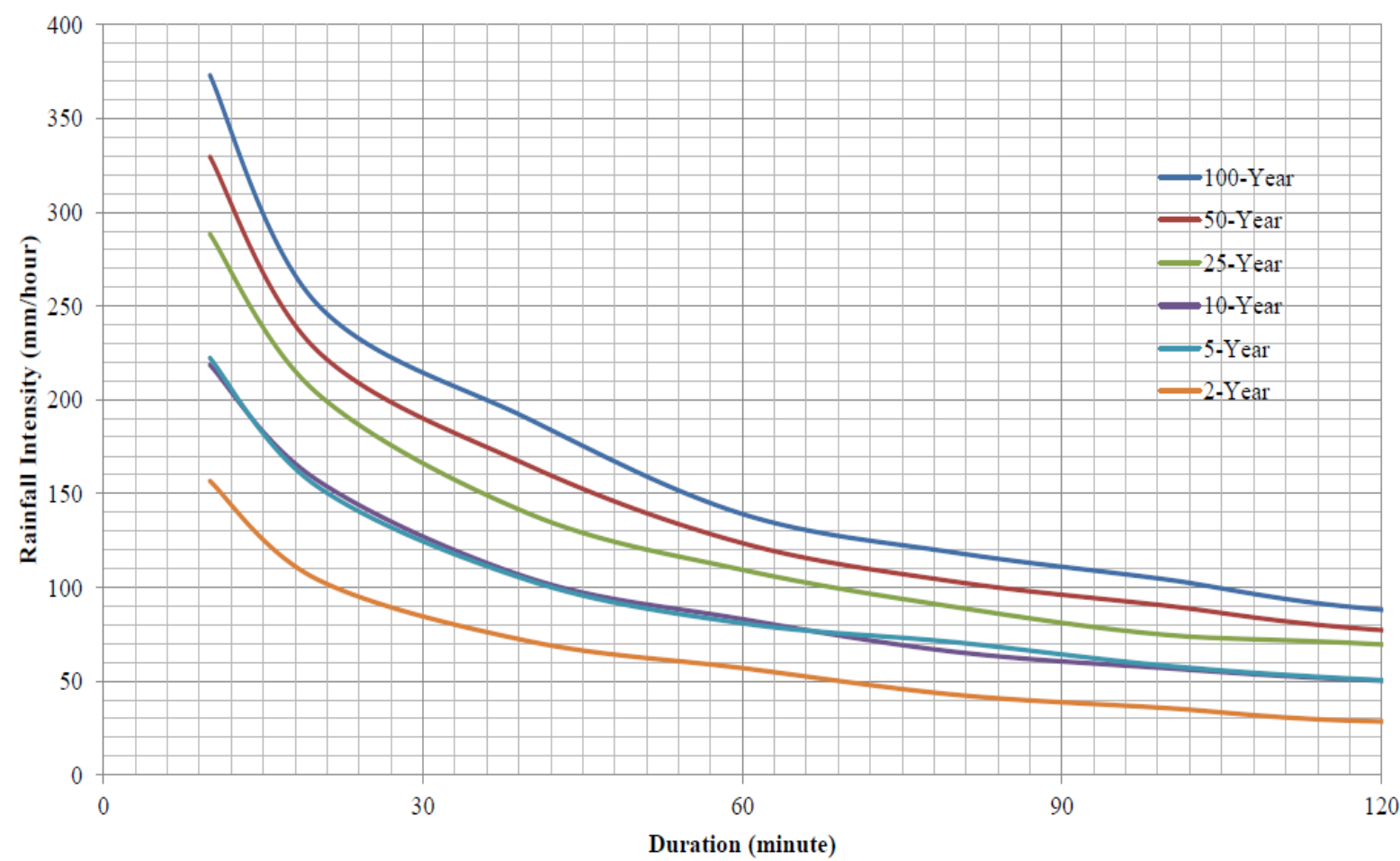

Figure 5: Developed rainfall intensity-duration-frequency (IDF) curve for Auchi

According to the IDF curve, rainfall estimates are increasing with increase in the return period and the rainfall intensities decrease with rainfall duration in all return periods. The model (curve) predicted higher intensities within durations less than 30 minutes across the different return periods which indicate a higher erosive power of the surface runoff during this period (duration) when compared to other durations e.g. 60 minutes, 90 minutes and 120 minutes.

The delineations of the catchments (to the head of the gully heads) are shown in Figure 6. 


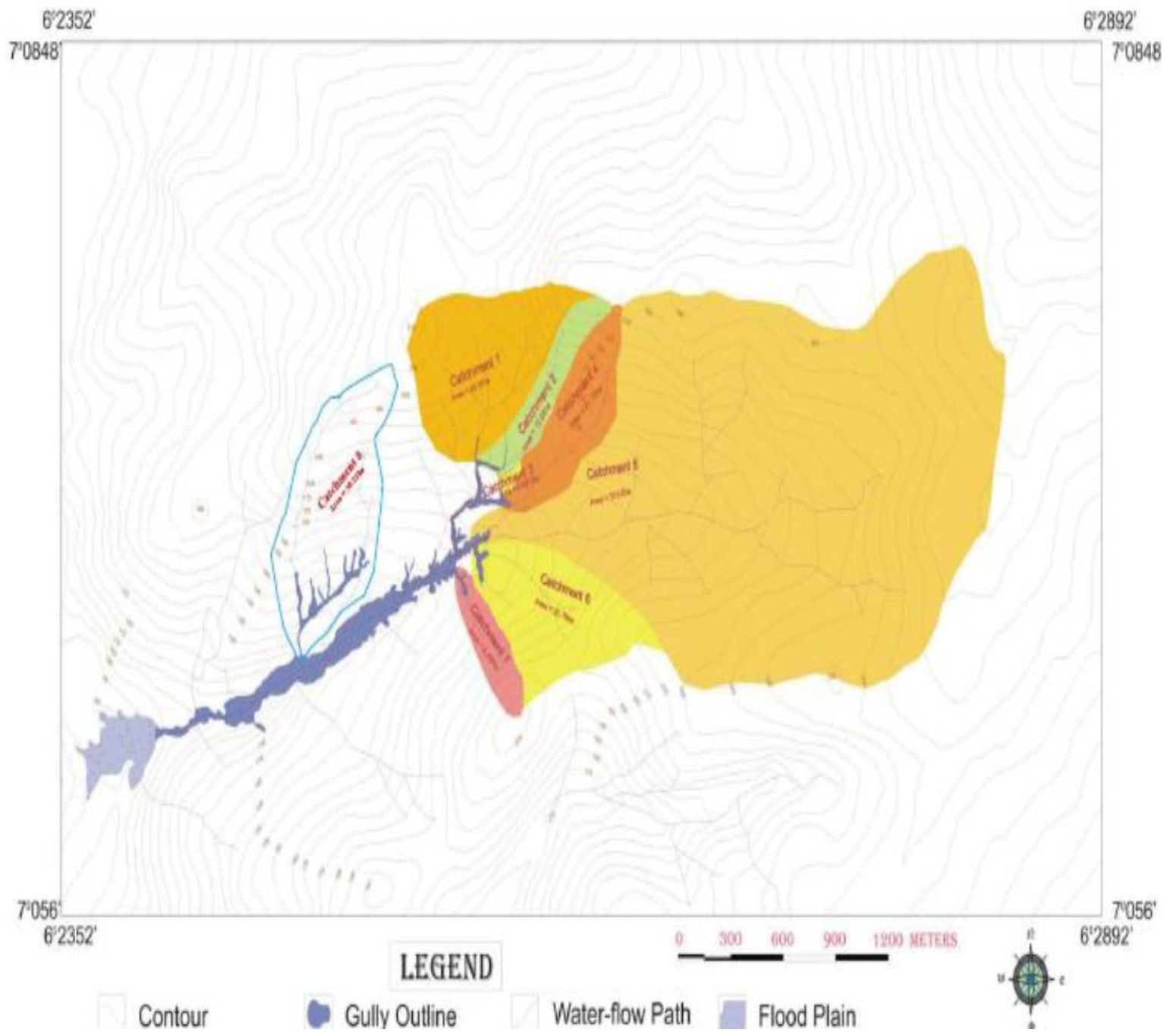

Figure 6: Catchment Area Delineation of Auchi Gullies (EDO NEWMAP, 2014)

Based on the findings of the hydrological studies, the cross section shows that the gully is V-shaped. Also taking into consideration the size of the gully (length and depth), the discharge of runoff and the size of the watershed/catchment area, it is described as a large gully. Also, due to the high intensity of rainfall over the area, it would be deduced that the study area possesses all the characteristics of an erosion prone area. Based on continuation, the Auchi gully complex can also be described as a continuous gully because it consists of many branched gullies.

\subsubsection{Findings of the Geotechnical study (Auchi Gully Complex)}

Table 4: Soil Test Summary Sheet

\begin{tabular}{|c|c|c|c|c|c|c|c|c|c|c|}
\hline Sample & Depth & & Siev & analysi & Sieve $\mathrm{s}$ & $(\mathrm{mm})$ & & NMC & Specific & Compaction \\
\hline & $(\mathrm{m})$ & 2.360 & 1.180 & 0.212 & 0.150 & 0.125 & 0.075 & $(\%)$ & Gravity $\mathrm{G}_{\mathrm{s}}$ & $\operatorname{OMC}(\%) \operatorname{MDD}\left(\mathrm{g} / \mathrm{cm}^{3}\right)$ \\
\hline Sample A & $0.00-3$ & 99.98 & 98.99 & 19.60 & 6.33 & 4.09 & 1.43 & 13 & 2.61 & $\begin{array}{ll}10 & 1.90\end{array}$ \\
\hline Sample B & $0.00-4$ & 99.96 & 98.26 & 17.67 & 7.08 & 4.83 & 1.88 & 14 & 2.65 & 1.94 \\
\hline
\end{tabular}

Physical observation of the gully cuts shows that the material is dry reddish fine silty sand underlain by whitish fine sand. The thickness of the fine silty sand varies from gully to gully. From the summary test sheet, it is deduced that the soil profile is loose and as such erodible. Auchi town is located in a rolling hill area and part of the town especially where gully erosion has occurred is a low lying pan with water flowing from north, south and east directions. The general soils of the area can be characterized as medium dense reddish silty sand (residual weathering product of an underlying sandy soil) underlain by fine whitish sand. At deeper location in the main gully, underlying shale was noticed. The gully materials are erodible and series of gullies were exacerbated by topography, high rainfall and manmade interferences. 
3.2.3. Assessment of existing slope stability

Figures 7, 8 and 9 provide the findings of the slope stability analysis obtained from SLOPEW software.

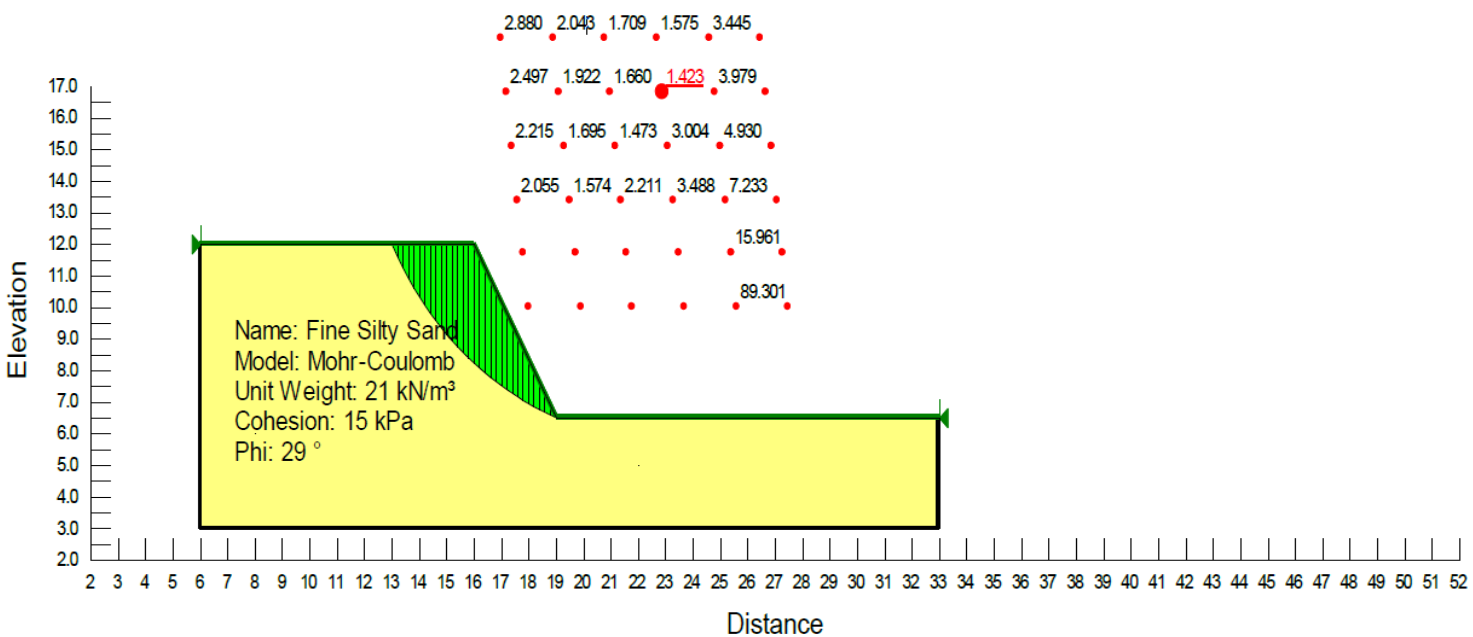

Figure 7: Slope stability analysis at $63^{\circ}$ at a height of $5.5 \mathrm{~m}$ for cohesion of $15 \mathrm{kPa}$.

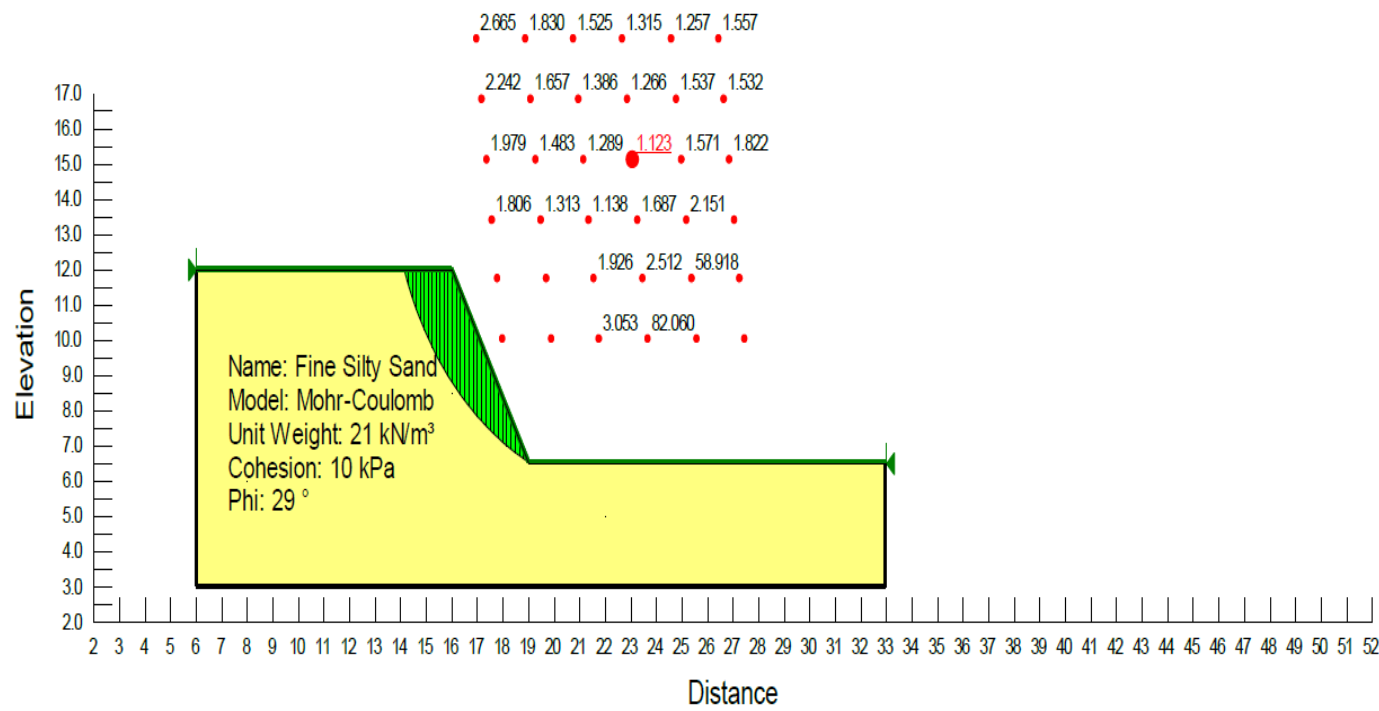

Figure 8: Slope stability analysis at $63^{\circ}$ at a height of $5.5 \mathrm{~m}$ for cohesion of $10 \mathrm{kPa}$

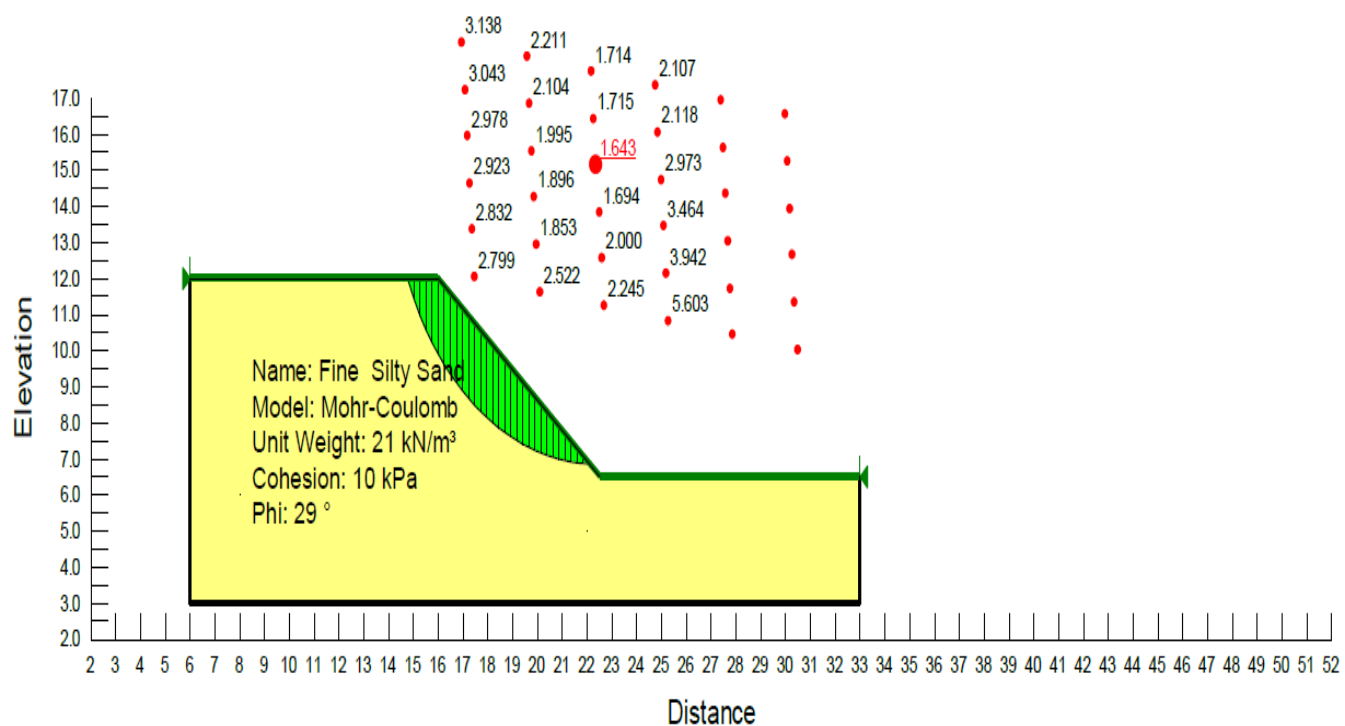

Figure 9: Slope stability analysis at $45^{\circ}$ at a height of $5.5 \mathrm{~m}$ for cohesion of $10 \mathrm{kPa}$ 
Figure 7 indicates that for cohesion of $15 \mathrm{kPa}$, the factor of safety is 1.4; the slope is stable in the long term. For cohesion of $10 \mathrm{kPa}$, the safety factor is 1.1 ; the stability in the long term is not ensured (Figure 8). As the existing slopes have been stable for more than 10 years, one can conclude that soil cohesion is close to or even higher than $15 \mathrm{kPa}$. Similarly, for slope at Figure 9, the factor of safety is 1.6. As could be deduced from the analysis, the existing slopes are stable and required to be made equal or gentler than $3 \mathrm{H}: 2 \mathrm{~V}$ in consideration of lower heights at $45^{\circ}$. However, it is recommended that slopes in areas of infrastructure need to be made equal or gentler than $3 \mathrm{H}: 2 \mathrm{~V}$ in consideration of better safety and probable effect of moisture.

\subsection{Ewu gully site}

3.3.1. Findings of the hydrological study (Ewu gully site)

Table 5 shows the values derived from ArcView GIS for Ewu gully site station for a 24-hour duration and Figure 10 shows the Rainfall Intensity-Duration-Frequency (IDF) curve.

Table 5: Ewu gully site station's value for a 24-Hr duration as derived from ArcView GIS

\begin{tabular}{|l|l|l|l|l|l|l|}
\hline Return Period & $100-$ Year & $50-$ Year & 25-Year & $10-$ Year & 5-Year & 2-Year \\
\hline $\begin{array}{l}\text { Rainfall } \\
\text { Intensity } \\
\text { (mm/hour) }\end{array}$ & 8.2011 & 7.8009 & 7.4008 & 6.7008 & 6.2005 & 5.3000 \\
\hline
\end{tabular}

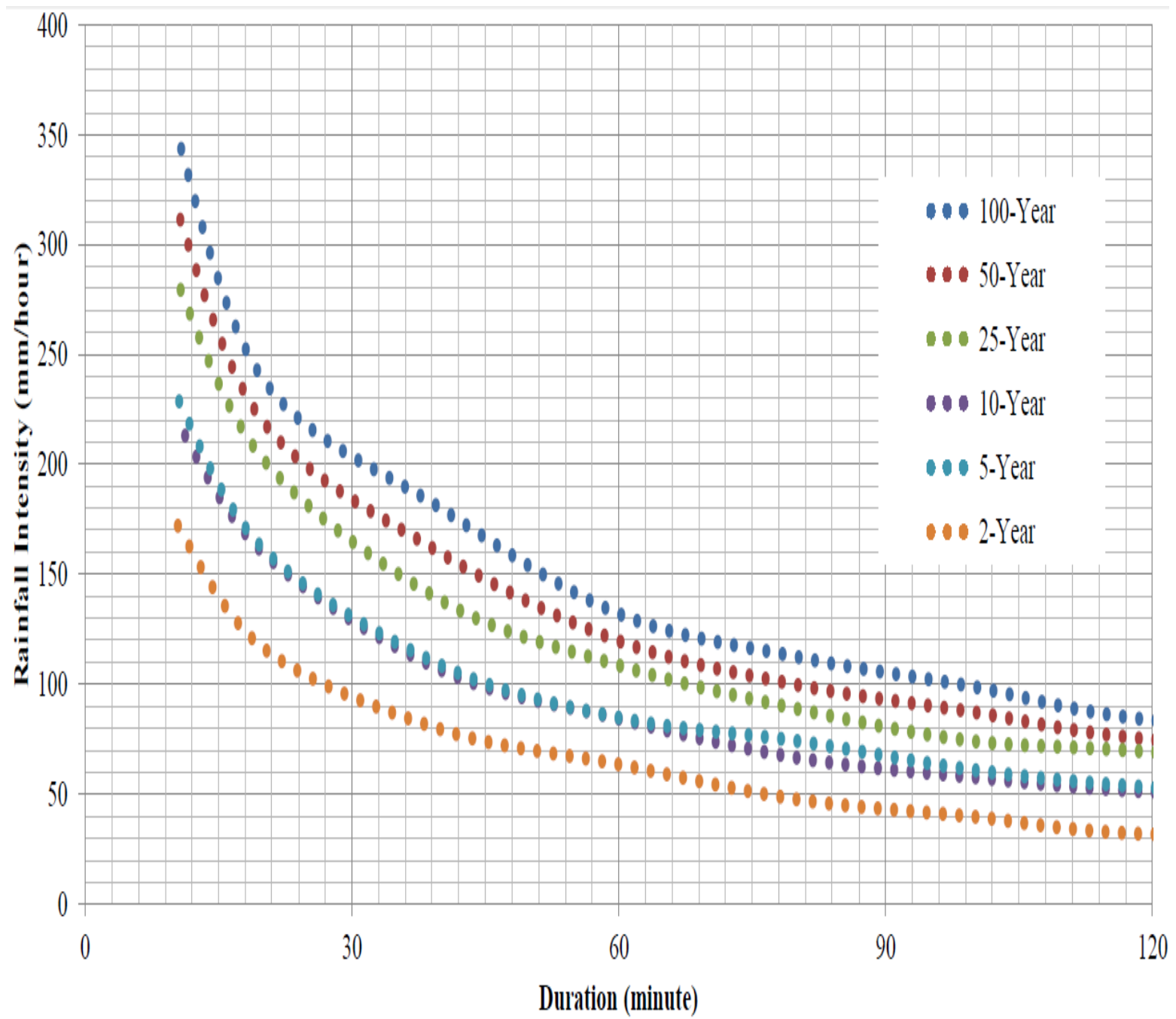

Figure 10: Developed rainfall intensity-duration-frequency curve for Ewu

According to the IDF curve, rainfall estimates are increasing with increase in the return period and the rainfall intensities decrease with rainfall duration in all return periods. The model (curve) predicted higher intensities within durations less than 30 minutes across the different return periods, indicating a higher erosive power of the surface runoff during this period (duration) when compared to durations of 60 minutes, 90 minutes and 120 minutes. 
The catchment that drains to the gully at Ewu is approximately 317.79 ha in size. The catchment is shown in Figure 11.

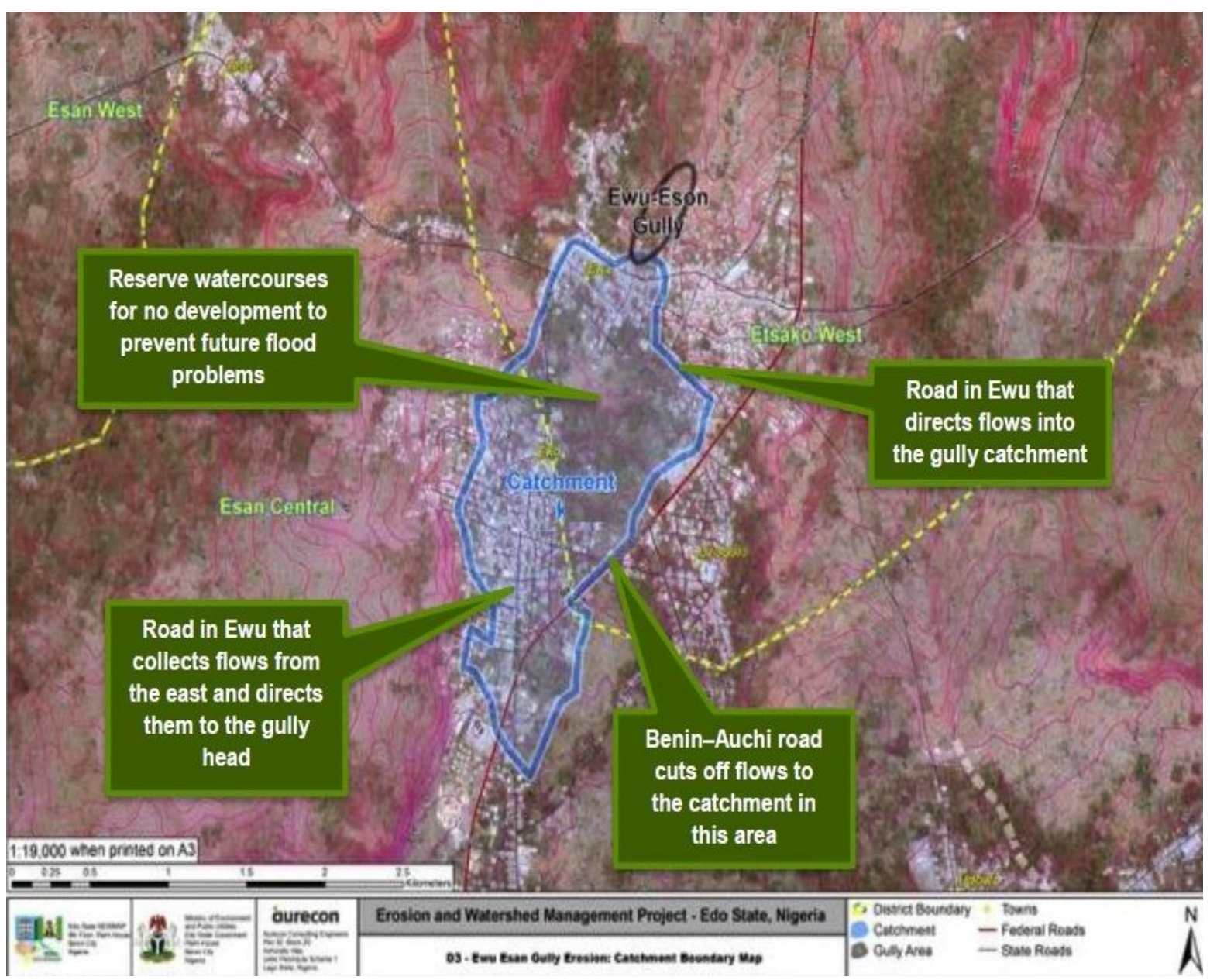

Figure 11: Catchment area delineation for Ewu gully (EDO NEWMAP, 2014)

Based on the findings of the hydrological studies, the cross section shows that the gully is V-shaped. Also taking into consideration the size of the gully (length and depth), the discharge of runoff and the size of the watershed/catchment area, it is described as a large gully. Based on its continuation, this gully is a discontinuous gully. The study also revealed that the study area possesses all the characteristics of an erosion prone area because of the high intensity of rainfall over the area.

\subsubsection{Findings of the geotechnical study (Ewu gully site)}

Table 6 shows the summary of the soil test result. The result of the soil test carried out showed that the specific gravity of the soil obtained varied between 2.42 to 2.66 (the soil is finely graded). The plasticity index of the soil sample varies from $13 \%$ to $33 \%$, and the soil optimum moisture content is about $15 \%$, indicating the presence of clayey soil. The minimum plasticity showed that the soil has a tendency to be eroded by water. The laboratory observation shows from AASHTO T180 - 70: BS 1377:75 that the material has from low to high plasticity and high compressible clay.

The triaxial compression in accordance with BS1377:75 had average friction angle of $30^{\circ}$ and average cohesion of $74 \mathrm{kN} / \mathrm{m}^{2}$ indicating that structures like drains and check dams could be constructed on the gully corridors. It is deduced that the soil(s) is fine grained with its drainage characteristics rated as fair to poor. 
Table 6a: Soil test summary sheet

\begin{tabular}{|l|l|l|l|l|l|l|}
\hline & \multicolumn{3}{|l|}{ Atterberg Limit } & \multicolumn{2}{l|}{ Compaction } \\
\hline Chainage & $\begin{array}{l}\text { Specific } \\
\text { Gravity }\end{array}$ & $\begin{array}{l}\text { LL } \\
(\%)\end{array}$ & $\begin{array}{l}\text { PL } \\
(\%)\end{array}$ & $\begin{array}{l}\text { PI } \\
(\%)\end{array}$ & $\begin{array}{l}\text { MDD } \\
\left(\mathrm{g} / \mathrm{cm}^{3}\right)\end{array}$ & $\begin{array}{l}\text { OMC } \\
(\%)\end{array}$ \\
\hline $\begin{array}{l}\text { LHS } \\
0+250\end{array}$ & 2.64 & 52 & 20 & 32 & 1.67 & 17.2 \\
\hline $\begin{array}{l}\text { LHS } \\
0+500\end{array}$ & 2.64 & 44 & 20 & 24 & 1.76 & 14.4 \\
\hline $\begin{array}{l}\text { LHS } \\
0+750\end{array}$ & 2.58 & 36 & 13 & 23 & 1.79 & 11.40 \\
\hline $\begin{array}{l}\text { RHS } \\
0+250\end{array}$ & 2.45 & 52 & 19 & 33 & 1.62 & 20.26 \\
\hline $\begin{array}{l}\text { RHS } \\
0+500\end{array}$ & 2.51 & 49 & 19 & 30 & 1.72 & 15.40 \\
\hline $\begin{array}{l}\text { RHS } \\
0+750\end{array}$ & 2.60 & 28 & 19 & 13 & & \\
\hline
\end{tabular}

Table 6b: Soil test summary sheet

\begin{tabular}{|c|c|c|c|c|c|c|c|}
\hline & \multicolumn{2}{|c|}{ Compression } & \multirow{2}{*}{$\begin{array}{l}\text { B.S Standard } \\
\text { Sieve Size } \\
(\mathrm{mm})\end{array}$} & \multirow[b]{2}{*}{$\begin{array}{c}\mathrm{CH} \\
0+000\end{array}$} & \multirow[b]{2}{*}{$\begin{array}{c}\mathrm{CH} \\
0+250\end{array}$} & \multirow[b]{2}{*}{$\begin{array}{c}\mathrm{CH} \\
0+500\end{array}$} & \multirow[b]{2}{*}{$\begin{array}{c}\mathrm{CH} \\
0+750\end{array}$} \\
\hline Chainage & $\begin{array}{l}\text { Cohesion } \\
\mathrm{C}\left(\mathrm{kN} / \mathrm{m}^{2}\right)\end{array}$ & $\begin{array}{l}\text { Angle of internal } \\
\text { friction }\left({ }^{\circ}\right)\end{array}$ & & & & & \\
\hline $0+000$ & 28 & 33 & 3.35 & 100 & 100 & 100 & 100 \\
\hline $\begin{array}{l}\text { Trial pit } \\
\text { Depth 3m }\end{array}$ & 130 & 29 & 2.36 & 99.94 & 99.38 & 97.46 & 100 \\
\hline Depth $3 \mathrm{~m}$ & 104 & 29 & 2 & 99.94 & 98.83 & 97.2 & 100 \\
\hline $0+250$ & 53 & 34 & 1.18 & 97.48 & 96.43 & 94.62 & 99.79 \\
\hline $0+750$ & 58 & 18 & 0.6 & 83.14 & 86.79 & 78.07 & 99.22 \\
\hline & & & 0.425 & 69.05 & 71.32 & 58.74 & 98.54 \\
\hline & & & 0.3 & 61.01 & 59.75 & 45.52 & 98.19 \\
\hline & & & 0.212 & 53.79 & 37.18 & 26.18 & 97.83 \\
\hline & & & 0.15 & 48.95 & 26.73 & 9.94 & 97.64 \\
\hline & & & 0.075 & 44.36 & 16.47 & 2.81 & 97.24 \\
\hline
\end{tabular}

\subsection{Conclusion}

The study concluded that the selected study areas possess all the characteristics of an erosion prone area which are: rainfall of very high intensity, steep slopes resulting in large runoff and soil with low organic content and relatively low shear strength obtained from the geotechnical investigations. It also revealed that the gully width and depth varied considerably from top to bottom. The cross section shows that the gully is U-shaped for Ekehuan gully and V-shaped for Auchi and Ewu gullies, indicating a large catchment area and a large volume of discharge passing through the gully.

In controlling the gullies, the following three control measures can be taken in order of priority (Desta and Adugna, 2012):

1. Improvement of gully catchments to reduce and regulate the runoff volume and peak rates.

2. Diversion of runoff upstream the gully area.

3. Stabilization of gullies by structural measures and accompanying revegetation.

In tropical and subtropical regions, such as Edo State, which receive large rains, all three methods will be useful for successful gully control.

\section{References}

Asikhia, O. M. and Nkeki, F. N. (2014). Mapping and Geovisualizing Topographical Data Using Geographic Information System (GIS). Journal of Geography and Geology, 6.

Boardman, J. (2001). Storms, Floods and Soil Erosion in the South Douns, East Sussex. Autumn and Winter 2000 -1 Geography, 86, pp. $346-355$.

British Standard Specifications B.S 1377: 1975. Method of Testing Soils for Civil Engineering Purposes. 
Bruce, C. (2006). Gully erosion and its control. Natural Resources and Water Managing Queensland's Natural Resources. Available at: http://www.qld.gov.au/dsitia/assets/soil/gully-erosion.pdf.

Desta, L. and Adugna, B. (2012). A field guide on gully prevention and control. Training Manual. Nile Basin Initiative (NBI). Addis Ababa, Ethiopia.

Edo State Nigeria and Erosion Management Project (EDO NEWMAP, 2014).

Ehiorobo, J. O. and Izinyon, O. C. (2011). Measurements and Documentation for Flood and Erosion Monitoring and Control in the Niger Delta States of Nigeria. Paper presented at FIG Working Week 2011, Bridging the Gap between Cultures Marrakech, Morocco.

Ehiorobo, J. O. and Izinyon, O. C. (2012). "Monitoring Gully Formation and Development for Effective Remediation and Control" Published online by the International Federation of Surveyors FIG at http//fig.net/publ/fig2012/papers/ts091.

Fabiyi, O. O., Ige-Olumide, O. and Enaruvbe, O. G. (2012). Spatial analysis of floodplains in Nigeria from spot satellite elevation data. In: Ayeni, B. \& Fabiyi, O. (Eds.), Geospatial technologies and digital cartography for national security, tourism and disaster management pp. 239-252. Proceedings of joint conference of Geoinformation Society of Nigeria and Nigerian Cartographic Association.

Federal Ministry of Lands and Housing (1989). Location Map of Ekehuan.

FEWS NET, Nigeria Special Report, June 1, 2016. Visualizing Trends in 1981-2015 Rainfall in Nigeria.

Hum, S., Bellanger, B., Borite, P. H., Podwojewski, P., Valentine, C., Velasquez, F. et al. (2005). Monitoring Soil Organic Carbon Erosion with Isotopic Tracers: Two case studies on cultivated tropical catchments with steep slopes. CRC Press, Bocaration, Florida, USA.

Nyssen, J., Poesen, J., Luyten, E., Veyret - Picot, M., Deckers, J., Haole, M. and Glovers, G. (2002). Impact of Road Building on Gully Erosion Risk: A case study from the Northern Ethiopian Highland. Earth Process and Land Forms.

Poesen, J., Nachtergaele, J., Verstraeten, G. and Valentine, C. (2003). Gully Erosion and Environmental Change: Importance and Research needs. Catena, 50, pp. $91-133$.

SLOPE/W. An Engineering Methodology. Geo-Slope International, Calgary, Canada, 2007.

Verstraeten, G. and Poesen, J. (1999). The Nature of Small Scale Flooding, Muddy Floods and Retention Pond Sedimentation in Central Belgium. Geomorphology, 29, pp. 275 - 292. 